\title{
Polak-wojownik. Wzorzec polskiego mężczyzny - mit czy rzeczywistość?
}

Streszczenie. Artykuł dotyczy kwestii o charakterze kulturowym. Jest próbą konfrontacji mitu o szczególnej waleczności Polaków z rzeczywistością historyczną, która od tego stereotypu jest odległa. Ponadto rozważania dotyczą przyczyn ukształtowania się takiego mitu i jego stałej obecności w kulturze narodowej Polaków.

Słowa kluczowe: Polak, mężczyzna, wojownik, rycerz, żołnierz - stereotyp kulturowy.

zorzec mężczyzny jako wojownika (przede wszystkim) jest stary jak świat. Świadczą o tym chociażby przekazy najstarszej literatury, że przywołamy fragment Iliady Homera, wedle którego kobieta winna zajmować się pracami domowymi, pozostawiając „mężczyźnie troskę o wojnę”. Podobnie widziała ten problem filozofia, postrzegając „męstwo” w kategoriach wojskowych, jako virtus militaris, żeby powołać się na słowa Platona, według którego: „Mężny jest i ten [...] co to w szeregu trwa i walczy z nieprzyjaciółmi"2. Podobnie rzecz ujmował bliższy nam w czasie Fryderyk Nietzsche, według którego: „Ku wojnie wychowany ma być mąż, niewiasta zaś ku wytchnieniu wojownika" 3. Swoisty mit męskości żołnierskiej ma więc długą tradycję zarówno w kulturze europejskiej, jak i w kulturze polskiej, a postrzeganie naszych antenatów w tych właśnie kategoriach nie powinno budzić najmniejszego zdziwienia. W odniesieniu do Polski kwestia ta - moim zdaniem - ma jednak dosyć specyficzne zabarwienie ${ }^{4}$. Wynika to w jednakiej mierze ze specyfiki naszych

*Wydział Historyczny, Instytut Historii, Zakład Historii Wojskowości, e-mail: olejnik@amu. edu.pl.

${ }^{1}$ Ho m er, Iliada, przekł., wstępem i komentarzem opatrzył J. Łanowski, Wrocław 1986, s. 160.

${ }^{2}$ Plat o n, Leches, przekł. W. Witwicki, Warszawa 1958, s. 47.

${ }^{3}$ F. N i etz s c he, Tako rzecze Zaratustra, przekł. W. Berent, Poznań 2006, s. 60.

${ }^{4}$ Zagadnienie to w ujęciu historii literatury bardzo interesująco opracował T. Tomasik, Wojna-męskość - literatura, Słupsk 2013. 
dziejów, zwłaszcza na przestrzeni dwu ostatnich stuleci (XIX i XX), jak również z uwarunkowań ustrojowych charakterystycznych dla Rzeczpospolitej szlacheckiej, które powodowały dalszy bieg wydarzeń, już po utracie własnego państwa.

Jeżeli na tytułowe zagadnienie spojrzymy w ujęciu chronologicznym, to mówiąc „Polak-żołnierz”, będziemy mieli na uwadze czas (mniej więcej) od drugiej połowy XIV w., gdy Królestwo Polskie wkroczyło w okres monarchii stanowej. Przesądza o tym szereg czynników, z których znaczenie podstawowe miało: $\mathrm{z}$ jednej strony wprowadzenie prawa pisanego ( $\mathrm{w}$ miejsce wcześniej stosowanego - prawa zwyczajowego), z drugiej natomiast - wykształcenie się w Polsce stanów. Stanów w rozumieniu grupy społecznej posługującej się odgórnie ustalonymi normami prawa pisanego. To zaś ściśle regulowało obowiązki każdej z owych grup, w tym także (obok fiskalnych, społecznych, kulturowych) obowiązki o charakterze wojskowym. Wprawdzie ostatecznie wykształcony wówczas podział społeczeństwa na tych, co się modlą (oratores), co pracują (laboratores) i co wojują (bellatores), miał swoją wcześniejszą metrykę (kształtował się wraz z formami ustroju feudalnego od wieku X), ale i tutaj w odniesieniu do Polski miał on daleko idącą specyfikę, która przesądza, że właśnie takie umocowanie w czasie jest najbardziej przekonujące. Wcześniejsza chronologicznie kultura rycerska miała charakter uniwersalistyczny, rozwinęła się na obszarach Europy wczesnośredniowiecznej jako pewien daleko ujednolicony wzorzec i w odniesieniu do ziem polskich trudno byłoby doszukiwać się jakiś cech specyficznych. Pomijając, że w Polsce jej (kultury rycerskiej) formy nie były tak dalece wysublimowane ani tak szeroko rozpowszechnione, jak na terenie Francji, Włoch czy Anglii. Nie znaczy to jednak, że poszukując odpowiedzi na tytułowe pytanie tego tekstu, możemy ten wcześniejszy okres całkowicie pominąć.

W rycerskim sposobie wojowania, w dobie kultury średniowiecznej nie tylko zapoczątkowany został wspomniany podział społecznych ról. Na tych, co się modlą - duchowieństwo; tych, którzy pracują - chłopi i mieszczanie; wreszcie na tych, których obowiązkiem (a także przywilejem) jest obrona obydwu wymienionych wcześniej grup społecznych. Bycie rycerzem zostało „obudowane” wieloma czynnościami o charakterze symbolicznym, estetycznym i religijnym. Należy w tym miejscu wskazać na takie czynności, jak: pasowanie na rycerza (rodzaj swoistej inicjacji na mężczyznę), wręczenie miecza, utrwalenie przekonania, że wojna jest zajęciem szczególnie godnym, pojmowanie wojny jako pięknej przygody, teatralizacja rycerskości poprzez elementy stroju (także odpowiedniego przystrojenia konia, który miał rycerzowi służyć na polu walki). Do tego doszła sakralizacja nie tylko np. samego obrzędu pasowania na rycerza, lecz także przyjęcie założenia, że rycerz-chrześcijanin jest obrońcą wiary. Udział Kościoła w tym procesie odgrywał - dodajmy - ogromną rolę. Poza wspomnianymi symbolicznymi czynnościami i stojącymi za nimi przesłankami ideowymi z postacią rycerza łączono szereg innych atrybutów, takich jak: kult bohaterstwa 
niepozbawiony jednak szacunku dla pokonanego przeciwnika, pełne galanterii zachowanie wobec kobiet oraz (a może przede wszystkim) rywalizacja męsko-męska. Uosobieniem tej ostatniej mogły być turnieje rycerskie, w których walczący mogli udowadniać swoje męskie, wojskowe „przewagi”. Zatem to wówczas utrwala się reguła, wedle której mężczyzna wywodzący się z uprzywilejowanej grupy społecznej feudałów (szlachty) niejako przywdziewa maskę żołnierskiej (rycerskiej) męskości. Wojaczka jemu tylko jest „przypisana” z samego faktu przynależności do szlachty, a wszystko to jest od pewnego momentu (w Polsce od połowy XIV w.) uregulowane prawem stanowionym.

Istotny wpływ na utrwalenie się tego kulturowego wzorca w świadomości „narodu szlacheckiego" (jak zwykło się określać ten stan) miały przemiany prawno-ustrojowe, ekonomiczne i społeczne, jakie nastąpiły w Polsce na przestrzeni $\mathrm{XV}$ w. Utrwalenie pozycji szlachty w strukturach państwa - na drodze kolejnych przywilejów - nad pozostałymi stanami (chłopstwem i miastami); stopniowo narastająca koniunktura na produkty szlacheckiego folwarku (co skutkowało wzrostem zamożności właścicieli ziemskich), a wreszcie zdominowanie władzy monarszej także w zakresie decydowania o sprawach wojskowych doprowadziły do całkowitej dominacji tego stanu. To były kwestie zasadnicze, w drugim „szeregu” czynników, które należy brać pod uwagę, szukając przyczyn swoistego „rozejścia” się wojennej praktyki z prawno-kulturowym kształtem obowiązków szlachty wobec kwestii wojskowych, były przemiany pola walki. W ślad za upowszechnianiem się broni palnej kończyła się epoka rycerskiego sposobu wojowania, zaczynała się epoka profesjonalizacji armii ze wszystkimi tego konsekwencjami (wzrastała rola piechoty, artyleria wymagała nie tylko ogromnych nakładów, lecz także fachowców, pojawiała się konieczność budowy nowego typu fortyfikacji, wzrastała konieczność utrzymywania wojska w stanie gotowości itd.). Na dalszy plan odchodziły indywidualne umiejętności w zakresie władania bronią, którymi szczyciło się średniowieczne rycerstwo. Tymczasem system ustrojowy utrwalony w XV w. w Polsce wspomnianych zmian zdawał się w ogóle nie brać pod uwagę. Nadal podstawowym obowiązkiem szlachcica pozostawało uczestnictwo w pospolitym ruszeniu (o jego anachronizmie przekonano się już podczas wojny trzynastoletniej), natomiast gdyby monarcha chciał posłużyć się siłami najemnymi, „gorset” ograniczeń stopniowo na władcę nakładanych (ostatecznym tego wyrazem będą ,artykuły henrykowskie" narzucone królom elekcyjnym od drugiej połowy XVI w.) działania takie skutecznie ograniczał.

Konieczność (zaznaczyć należy - coraz to bardziej lukratywna) zajmowania się folwarkiem, niechęć do zaakceptowania zmian w strukturach zbrojnych państwa, które by wymagały zasadniczych zmian o charakterze ustrojowym, powodowały, że szlachcic stopniowo z dawnego „rycerza” stawał się „ziemianinem”. W znacznej mierze sprzyjało temu to, że po ostatecznym rozstrzygnięciu kwestii krzyżackiej (w rezultacie wojny trzynastoletniej) aż do połowy wieku XVII Rzeczpospolitej Obojga Narodów w istotny sposób nie zagrażało 
niebezpieczeństwo zewnętrzne. Owszem wojny miały miejsce: Zygmunt August zmagał się z Moskwą, Batory zwycięsko walczył z Iwanem Groźnym o Inflanty, potykano się ze Szwedami u progu XVII w., coraz częściej dochodziło do starć z Turcją, ale wszystko to były konflikty na obrzeżach potężnego państwa. Szlachta zdecydowanej większości ziem koronnych żyła w warunkach pokoju i stopniowo narastającej zamożności. Tymczasem jest nieomal regułą, że w takiej sytuacji, w czasach pokojowych funkcja wojownika, żołnierza - obrońcy kraju, usuwa się na dalszy plan, natomiast w tym samym czasie utrwala się ona w sferze mitu. W sferze swoistego idealnego wzorca, obudowanego ponadto bagażem sentymentalnych wspomnień o faktycznych, a często i urojonych, niegdysiejszych sukcesach.

Ostatecznie postrzeganie szlachty jako „rycerstwa” dokonało się w okresie sarmatyzmu. Przyczyn tego stanu rzeczy było kilka. Zacznijmy od tego, że $\mathrm{w}$ gruncie rzeczy szlachcic nie miał innego wyboru w poszukiwaniu wzorca, który by przystawał do jego dominującej pozycji w państwie. Wzorzec zajęć mieszczańskich (kupiectwo, rzemiosło) nie był przez szlachtę akceptowany. Zajęcia tego rodzaju uważane były przez stan uprzywilejowany jako „sprośne”, „smrodliwe”, a zajmowanie się nimi mogło spowodować utratę szlachectwa. Praca na roli, ,przynależna” do stanu chłopskiego, ze zrozumiałych względów także nie przystała „szlachetnie urodzonym”. Wybór był niezbyt wielki - poświęcenie się stanowi duchownemu albo piastowanie urzędów. Te ostatnie, poza funkcjami wojskowymi, nie cieszyły się szczególnym poszanowaniem szlacheckiego ogółu, a specyfika ustrojowa państwa osłabiała ich faktyczne znaczenie. Częstokroć walor jakiegoś urzędu sprowadzał się do coraz to bardziej rozbudowanej tytulatury, za którą nie postępowały ani apanaże, ani też faktyczne możliwości działania.

Sarmatyzm, jako formacja kulturowa typowa dla szlacheckiej Rzeczypospolitej, pojawił się na przełomie XVI i XVII w. (i dominował w zasadzie aż do schyłku XVIII stulecia) w procesie poszukiwania historycznej tożsamości. Jego istotą było przekonanie, że Polacy (w rozumieniu - szlachta) pochodzą od starożytnego plemienia Sarmatów, o którym wzmiankował Ptolemeusz, a którego pierwotne siedziby znajdowały się na północno-wschodnich rubieżach Europy, na styku z Azją. Miał to wprawdzie być lud w rozumieniu Rzymian „barbarzyńców”, ale oznaczających się - nade wszystko - szczególną walecznością. Obok tejże Sarmaci - konni wojownicy - jak utrzymywano, charakteryzowali się takimi przymiotami, jak: szlachetność, duma i poczucie wyższości w stosunku do innych narodów. To kulturowe imaginarium doskonale pasowało nie tylko do wyobrażeń, lecz także do faktycznej roli stanu szlacheckiego, który wojował konno na ogromnych przestrzeniach wschodniej Rzeczypospolitej, był dumny z ustroju państwa, w którym dominował nie tylko nad mieszczaninem czy chłopem, lecz nawet potrafił ograniczyć władzę monarchy, a na inne narody patrzył z poczuciem wyższości. Dodajmy, że to ostatnie było całkiem uzasadnione, zważywszy, 
że zarówno na wschodzie (despotyczny car), jak i na zachodzie (sprawujący rządy absolutne król) mogli arbitralnie przesąadzać o losie swoich poddanych, podczas gdy nad Wisłą czy Niemnem to monarcha zabiegał o ich poparcie.

Wojujący konno szlachcic - Sarmata (specyfika teatru działań preferowała jazdę) co najmniej od połowy XVII w. zyskał atrybut „obrońcy wiary”, zważywszy, że głównymi przeciwnikami byli: „heretycy” (Szwedzi), poganie (Turcy) albo schizmatycy (Moskale). Ta rola „przedmurza chrześcijaństwa” przypisywana Rzeczypospolitej dodatkowo legitymizowała szlachetne poczucie wyższości i nadzwyczajną pozycję w państwie. Ogromną rolę w stopniowym utwierdzaniu tych obiegowych poglądów i wysokiej samooceny odgrywał Kościół katolicki, żywotnie zainteresowany w zwalczaniu wymienionych nacji, także swoich wrogów. Szlachcic w propagandzie kościelnej był nie tylko „mężny, ale i pobożny”. Stopniowo narastającemu przekonaniu, że ,z Bożą pomocą nie straszny nam żaden wróg" nie towarzyszyły jakże konieczne reformy w coraz to bardziej zacofanej strukturze zbrojnej państwa. Te silne konotacje religijne widoczne były zwłaszcza po „potopie” (atak Szwedów na Jasną Górę, który w gruncie rzeczy został utrwalony w publicznym oglądzie bardzo mocno, ale w sposób daleki od prawdy) oraz wiązały się ze zmaganiami z Turcją. Dowodem na zaangażowanie Kościoła w propagowaniu sylwetki szlachcica - obrońcy wiary, może być działalność ks. Piotra Skargi (por. Żotnierskie nabożeństwo) czy propagowanie tzw. żołnierskich modlitewników. Ta swoista propaganda utwierdzająca szlachtę w przekonaniu, że od jej zaangażowania na polu walki zależy bezpieczeństwo kraju, nie powodowała zasadniczych zmian w strukturach wojskowych Rzeczypospolitej, które coraz to bardziej rozmijały się ze zmianami na polu walki, zwłaszcza tymi, które nastąpiły w okresie wojny trzydziestoletniej ${ }^{5}$. Szlachta wprawdzie zdawała sobie sprawę z konieczności pewnych zmian, już dużo wcześniej pisali o tym publicyści-reformatorzy, jak Andrzej Frycz Modrzewski, Józef Wereszczyński czy Piotr Grabowski, ale wymagałyby one korekty całego ustroju państwa, a na to zgody nie było. Przekonanie szlachty, że „własnymi piersiami” osłoni Rzeczpospolitą, nadzieja, że potężne rody magnackie wojskami prywatnymi w razie konieczności zapobiegną katastrofie, a w ostatecznym rachunku - spoglądanie ku niebiosom, skąd pomoc dla "katolickiego narodu wybranego" nadejść musi - dopełniały klimatu, w którym utwierdzał się mit szlachcica-rycerza. Mit coraz dalszy od rzeczywistych potrzeb pola walki i coraz dalszy od faktycznego udziału tej grupy społecznej w świadczeniach na rzecz obronności państwa.

W utwierdzaniu wzorca szlachcica - pobożnego i walecznego wojownika udział brała także literatura. To spod pióra Jana Kochanowskiego (por. Pieśń XIX zwana Pieśnia o dobrej stawie) wyszło przekonanie, wedle którego „Prostak to, który wojsko z wielkości szacuje. [...] Zwycięstwo liczby nie chce, męstwa

\footnotetext{
${ }_{5}^{5}$ P.H. Wil s o n, Wojna trzydziestoletnia 1618-1648. Tragedia Europy, Oświęcim 2017.
} 
potrzebuje", a w innym miejscu tenże stwierdza, że to szlachcie właśnie „Bóg dał serce i siłę" do walki z niewiernymi. Dodajmy, że Kochanowski nie był jedynym, który sławił dzielność „Sarmatów” na polu bitewnym. Podobnie czynili Wacław Potocki (Wojna chocimska), Szymon Starowolski (Sarmatiae bellatores), Mikołaj Sęp Szarzyński (Poezje), Wespazjan Kochowski (Klimaktor IV obejmujący dzieje Polski pod panowaniem króla Michała) i wielu innych pisarzy z okresu baroku. W tym miejscu warto zauważyć, że niektóre przynajmniej wydarzenia z pól bitewnych zdawały się potwierdzać słuszność takiego rozumowania. Czyż bowiem nie „męstwo" husarii zadecydowało o zwycięstwie nad przeważającymi liczebnie oddziałami szwedzkimi pod Kircholmem (1605)? Czy w podobnych sytuacjach dysproporcji sił nie zwyciężał Turków Jan III pod Chocimiem (1673)? Albo tenże nie gromił czambułów tatarskich w roku 1672? Trudno też powstrzymać się od refleksji, że podobne rozumowanie będzie później wielokrotnie towarzyszyło polskiemu spojrzeniu na wojnę z liczniejszym wrogiem, chociażby w kolejnych powstaniach narodowych XIX w., a kończąc na powstaniu warszawskim z roku 1944.

Powstaje pytanie: czy szlachta ten rycerski obraz zaakceptowała? W sferze kultury - jak najbardziej, na płaszczyźnie samooceny również. Wyrazem tego były nie tylko liczne utwory literackie sławiące waleczność i inne cnoty tego stanu, lecz także wiele innych elementów towarzyszących szlacheckiemu bytowaniu. Wystrój dworu zawierał liczne elementy uzbrojenia, orientalizacja stroju (następowała w wyniku częstych - także na płaszczyźnie wojennej - kontaktów z Turkami) obejmowała liczne elementy wyposażenia wojskowego, portret trumienny zdominowany był przez podkreślanie żołnierskiej postawy zmarłego, a pośmiertne panegiryki podnosiły zasługi denata na polu walki, podobnie czyniły panegiryki i cała rozbudowana pompa funebris. A rzeczywistość? Tutaj możemy posłużyć się kilkoma, jakże znamiennymi przykładami.

Wojny Batorego z Iwanem Groźnym o Inflanty słusznie nazywa się niekiedy wojnami ,proszonymi”. Król musiał bowiem zabiegać w sejmie o stosowne fundusze na ten cel. I o ile na dwie pierwsze wyprawy udało się (nie bez trudu) środki takie pozyskać, to przed trzecią wyprawą posłowie oświadczyli, że ta musi być ostatnia, bo więcej już na wojnę podatków nie uchwalą. W roku 1605, gdy Szwedzi w swoich zapędach o Inflanty zagrozili Rydze, która wszak jako port wywozowy była dla szlachty litewskiej tym, czym Gdańsk dla Koroniarzy, pospolite ruszenie tamtych terenów przybyło na miejsce koncentracji, oświadczając hetmanowi Chodkiewiczowi, że oni tylko „na dwa tygodnie”, bo zbliża się czas żniw. Przed wyprawą wiedeńską Kościół rozwinął niebywałą propagandę na jej rzecz. Powszechne było odwoływanie się do tego szlachty jako „obrońców wiary”. Dodajmy, że Sobieski cieszył się ogromnym uznaniem jako zwycięski pogromca Turków we wcześniejszych zmaganiach. I co? Ano to, że pod Wiedeń

\footnotetext{
${ }^{6}$ J. Koc han ow ski, Dzieła polskie, oprac. J. Krzyżanowski, t. I, Warszawa 1976, s. 264.
} 
dotarły tylko wojska koronne, bo Litwini wcale na wojaczkę się nie śpieszyli i dołączyli do wojsk królewskich dopiero w bitwie pod Parkanami.

Interesująco wyglądały te kwestie także w literaturze. Analiza prac teoretycznych i ówczesnej ,publicystyki” (że posłużymy się współczesnym terminem) pozwala stwierdzić, że obce im były jakiekolwiek nawoływania do polityki ekspansywnej, do wojen zdobywczych. Jedynym wyjątkiem w tym zakresie jest niewielkie dziełko ks. Pawła Palczowskiego Kolenda moskiewska, w którym autor peroruje, że tak jak Anglicy, Francuzi czy Hiszpanie mają swoje kolonie hen za morzem, tak szlachta powinna zajmować obszary aż po Ural. Było to jednak przysłowiowe wołanie na pustyni, bo szlachcic wolał w dobrej kompanii miód spijać, niż na wojnę się wyprawiać. Także i samo wojskowe przygotowanie „panów braci” w miarę upływu czasu do tzw. okazowania raz do roku przed starostą ograniczone, odbywało się, jak to określił jeden z pisarzy XVI stulecia, w ten sposób, że ,[...] jeden przyjedzie na koniu, drugi na wole a trzeci zgoła na maciorce". Powtórzmy to raz jeszcze - im mniejsze było szlacheckie, bezpośrednie zaangażowanie w wojny, jakie toczyła Rzeczpospolita, tym bardziej utwierdzał się ten obraz szlachcica - Sarmaty - rycerza na koniu i z karabelą u pasa. W tym stanie rzeczy można wręcz stwierdzić, że w gruncie rzeczy stanowi szlacheckiemu przypisać można pacyfizm. Wynikał on z wielu przesłanek, pośród których podstawowa była ta, że przynajmniej do połowy stulecia XVII szlachta nie miała o co wojować ${ }^{7}$.

Podstawowy imperatyw większości wojen rozgrywanych wówczas w Europie to były wojny o panowanie nad obszarami, co do których był spór o przynależność; takie, w których konflikt dotyczył dążenia do wyemancypowania się spod dotychczasowej kurateli (Niderlandy od Hiszpanii) albo też były to wojny o podłożu religijnym. O co zatem miał wojować polski szlachcic, przed którym otworem stały ogromne przestrzenie na Ukrainie, który w wyniku dosyć powierzchownego podejścia do nowinek religijnych zdobył się na kompromis z różnowiercami? Nie po to „obłożył” króla (w obawie przed absolutystycznymi zapędami monarchy) zakazami dotyczącymi kwestii wojowania, nie po to powstrzymywał Batorego czy Władysława IV w reformach wojskowych, aby rezygnować ze spokojnego żywota. Szlachta w XVI w. i znacznej części pierwszej połowy stulecia następnego miała zbyt dużo do stracenia, aby przyzwalać na daleko idące zmiany w strukturach zbrojnych państwa. Do tego potrzeba było zachodu na płaszczyźnie ustrojowej. Specyfika Rzeczpospolitej, której rozległość osłabiała i tak już słabą władzę monarchy, natomiast przez system klientelizmu podnosiła rolę lokalnych magnatów, powodowała, że w chwili szczególnej potrzeby szlachta mogła liczyć na to, że prywatne wojsko wielmoży stanie w szranki z nieprzyjacielem, pozwalając jej na dalszy minimalny tylko udział w wojowaniu. Dodajmy, że ten ostatni czynnik (wojska magnackie) nabrał znaczenia w szczególności po „,potopie”, gdy

\footnotetext{
${ }^{7}$ S. Estreicher, Pacyfizm w Polsce XVI stulecia, Poznań 1930.
} 
kraj został w znacznym stopniu zniszczony i szlachta musiała w pierwszym rzędzie zadbać o odbudowę własnego ekonomicznego zaplecza.

Mimo że wartości żołnierskie były bardzo wyraziście zaznaczone w szlacheckim bytowaniu (za zasługi na polu walki można było otrzymać szlachectwo) i na płaszczyźnie kulturowej, stan ten - jak zaznaczyliśmy - hołdował postawie pacyfistycznej. Gdy zaistniała potrzeba, aby stawić czoła licznym wojnom w wieku XVII (jak obliczono, na całe to stulecie tylko przez 30 lat Rzeczpospolita wojna była od działań orężnych), szlachta z trudem, bo z trudem, ale na podatki wojskowe się godziła (pomińmy to, że nie wpływały one do skarbca na czas, co było przyczyną żołnierskich buntów i swawoli), ,stawała” pod bronią z rozmaitym skutkiem - ale nie zmieniało to zasad działania struktur obronnych państwa. Można zatem mówić, że szlachecka wojowniczość tamtych lat była wojowniczością „wymuszoną", co nie przeszkadzało, że na płaszczyźnie kulturowej wzorzec szlachcica-żołnierza trwał w najlepsze. Taka sytuacja militarna, na płaszczyźnie strukturalnej, przetrwała do końca I Rzeczpospolitej, a o niezmiennie pacyfistycznej postawie szlachty świadczy chociażby jej stosunek do postanowień Konstytucji 3 maja. Zawarte w niej szczytne postanowienia o konieczności utworzenia armii 100-tysięcznej pozostały na papierze, a przecież nie trzeba było być wielkim politykiem, aby dostrzegać, że upadek państwa jest bliski.

W czasy rozbiorowe społeczeństwo szlacheckie wkraczało z silnie osadzonym przekonaniem o swoich szczególnych zasługach dla ojczyzny na polach bitewnych, z wzorcem szlachcica - Sarmaty - wojownika. Stulecie XIX miało nie tylko ten wzorzec pielęgnować, lecz także ostatecznie go ukształtować przez dodanie nowych znaczeń. Zadecydowały o tym trzy czynniki. Pierwszy (zasadniczy) to brak własnego państwa i konieczność walki o jego odzyskanie. Ten wymóg niejako przesądzał o szczególnym traktowaniu wszystkiego, co było związane z siłami zbrojnymi. Była to podstawowa determinanta postawy Polaka-patrioty. Czynnik drugi to społeczna ewolucja w strukturach zbrojnych, a momentem decydującym były tutaj wydarzenia będące pokłosiem Wielkiej Rewolucji Francuskiej z końca XVIII w. Zmiany były fundamentalne, ponieważ o ile wcześniej armie miały charakter ponadnarodowych sił najemników (z kadrą oficerską rekrutującą się z górnych warstw społecznych), to w XIX stuleciu wojsko miało charakter armii narodowych, w szeregach których służył ogół obywateli z powszechną możliwością dostępu do stanowisk dowódczych. Czynnik trzeci to charakter dominującej formacji kulturowej, którą przez nieomal całe XIX stulecie był romantyzm.

Przełom stuleci XVIII i XIX to okres, w którym w Europie wojna stała się czynnikiem kształtującym rzeczywistość na skalę wcześniej niespotykaną. Rewolucja francuska, a później wojny napoleońskie zadecydowały o granicach państw, które przetrwały do początków XX w. Jak wspomnieliśmy, obok innych zmian dokonała się ta $\mathrm{w}$ strukturze społecznej sił zbrojnych. Wcześniejszego żołnierza-najemnika zastąpił żołnierz-obywatel. Skutek był taki, że do służby wojskowej predestynowali nie tylko przedstawiciele warstw uprzywilejowanych, 
lecz także pozostałych grup społecznych. W odniesieniu do ziem polskich proces ten zaistniał po raz pierwszy, w ograniczonym zakresie, podczas insurekcji kościuszkowskiej, a następnie w Legionach. W okresie późniejszym w kolejnych zrywach powstańczych udział pozaszlacheckich warstw społeczeństwa będzie ograniczony zarówno przez czynnik różnic klasowych, jak i kulturowych (początkowo niska, a potem powoli rodząca się świadomość narodowa chłopów i mieszczan). Sytuacja w tym względzie nabierze przyśpieszenia dopiero pod koniec XIX stulecia, gdy pojawiający się ruch robotniczy (Polska Partia Socjalistyczna) i masowe partie polityczne (chłopskie i robotnicze) wprowadzą czynnik narodowowyzwoleńczy do swoich programów.

Okres wojen napoleońskich, pozostały po nich mit Napoleona „Boga wojny” w znaczący sposób „wpasowywał się w polską symbolikę Polaka-żołnierza. Walki u boku napoleońskiej Francji, Legiony, współudział u boku Wielkiej Armii w wyprawie na Moskwę, armia Księstwa Warszawskiego, a nawet Królestwa Polskiego z epopeją powstania listopadowego tworzyły ciąg tradycji, w której pojęcie „Polak-żołnierz” znajdowało swoje potwierdzenie. Niebagatelne znaczenie miała przy tym galeria znaczących postaci, do których odwoływała się masowa wyobraźnia. Poczynając od Jana Kilińskiego i Tadeusza Kościuszki, przez Kazimierza Pułaskiego, Jana Henryka Dąbrowskiego, Józefa Wybickiego, Piotra Wysockiego, Józefa Sowińskiego, Józefa Dwernickiego, aż po Ignacego Prądzyńskiego, Józefa Bema i Romualda Traugutta - wszyscy oni byli postrzegani jako kontynuatorzy dawnych, sarmacko-szlacheckich tradycji militarnych. Dodajmy, że te ostatnie pozostawały znękanemu społeczeństwu pozbawionemu własnego państwa jedną z nielicznych płaszczyzn, na których można było odnaleźć elementy sukcesów, wspaniałych zwycięstw. Tym chętniej zatem do nich sięgano.

Postrzeganie polskiego mężczyzny w kategoriach żołnierza (przede wszystkim) odbywało się ponadto w sprzyjającym klimacie kulturowym. Polegało to na tym, że wiodącą rolę na płaszczyźnie działań zmierzających do odzyskania własnego państwa odgrywała szlachta, która stopniowo stała się zalążkiem wyłaniającej się z niej inteligencji. Kultura polska, w jej inteligenckiej formie, wywodziła się bez reszty z tradycji szlacheckiej i do jej tradycyjnych wartości się odwoływała. Nie było tam miejsca na tradycje mieszczańskie, nie było na chłopskie (co jeszcze bardziej zrozumiałe), pozostawało jedynie to, co w tradycji szlacheckiej najbardziej utrwalone, w tym także mit Polaka-wojownika. Ten klimat, w którym wartości pożądane (walka o wolność) były w najwyższym stopniu eksponowane, $w$ istotny sposób utrwalała specyficzna tamtych lat romantyczna literatura. Romantyzm w szczególny sposób hołdował i propagował postaci bohatera. Częstokroć samotnego, oddanego „sprawie”, bardzo często z góry skazanej na klęskę, ale zawsze gotowego do poświęceń aż po utratę życia. Zestawienie takich właśnie reguł postrzegania rzeczywistości prowadzi nas do prostego wniosku, że kolejne nieudane powstańcze zrywy narodowe (powstania kościuszkowskie, 
listopadowe, krakowskie 1846 r., styczniowe), śmierć w walce, tragiczne losy wywiezionych na Sybir czy udających się na emigrację - wszystko to powodowało, że przegranych w walce otaczał narastający „klimat męczeństwa”. Wzniosłość „sprawy”, o którą walczono, pozwalała nawet stwarzać w literackim opisie swoisty „kult śmierci”. Był to swego rodzaju „paradygmat tragicznego bohaterstwa”. Stał się on obecny w wielu dziełach literackich, w obchodach kolejnych rocznic nieudanych walk zbrojnych, w symbolice (przykładem - „biżuteria patriotyczna” po upadku powstania styczniowego), a przede wszystkim w pieśniach patriotycznych. Któż nie zna słów Warszawianki z 1831 r.: „Kto polegnie wolnym będzie, a kto poległ - wolnym już; czy tragicznej w swej wymowie pieśni z okresu Powstania Styczniowego: Poszli nasi w bój, bez broni”.

Przez całe stulecie XIX zbrojna walka postrzegana była jako podstawowy i najważniejszy obowiązek polskiego mężczyzny. Był to chyba najsilniej umocowany $\mathrm{w}$ zbiorowej świadomości swoisty paradygmat, swoista patriotyczna „matryca”. W sposób szczególny (ze wspomnianych względów) dotyczyło to wiodącej grupy polskiego społeczeństwa szlachty/inteligencji, co znajdowało swój wyraz w swoistym patriotycznym ,terrorze”. Polak-patriota miał podstawowy obowiązek przygotowywać się do pełnienia obowiązków żołnierskich: w zrywie powstańczym, w pracy konspiracyjnej, w tajnych działaniach doskonalących wojskowe umiejętności. Finałem tego miała być albo walka o niepodległość, albo (w razie przegranej) - śmierć. Tego swoistego mitu nie można było kwestionować, nie było od niego odwrotu, nie było też alternatywy, czego dowodem może być to, że w zasadzie nigdy nie uzyskał szerszego uznania wzorzec Polaka: inżyniera, odkrywcy, fabrykanta. Praca organiczna, aczkolwiek w niektórych regionach ziem polskich z dużym sukcesem wcielana w życie (Wielkopolska), postrzegana była jedynie jako sposób na przetrwanie, a nie jako droga do odzyskania niepodległości.

Do utrwalenia tego wzorca Polaka-żołnierza w decydujący sposób przyczyniały się różne dziedziny narodowej kultury. W pierwszym rzędzie literatura, że wymienimy cykle powieści historycznej nie tylko Henryka Sienkiewicza, lecz pozostającego trochę w jego cieniu - Ignacego Kraszewskiego czy Elizę Orzeszkową, później Stefana Żeromskiego (aczkolwiek ten ostatni prezentował nieco odmienny ogląd przeszłości wojennej). A przecież już nieco wcześniej rycerskie ,przewagi” przodków z ogromnym powodzeniem zaprezentował Jan Ursyn Niemcewicz w Śpiewach historycznych ${ }^{8}$. Nie miało wielkiego znaczenia, że trylogia Sienkiewicza nie u wszystkich wzbudzała zachwyt (por. krytyczne wypowiedzi Bolesława Prusa w jego artykułach na łamach warszawskiego „Kuriera Codziennego"), że w skrajnych ocenach koronne dzieło naszego pierwszego na polu literatury noblisty Stanisław Brzozowski, w swoim podstawowym

${ }^{8}$ J.U. N i e m c e w i c z, Śpiewy historyczne, Kraków 1816. Praca do końca XIX stulecia miała 16 wydań. 
dziele Legenda Młodej Polski, nazwał szkodliwym. Zarzucał on Sienkiewiczowi, że utrwala on szlacheckie wady i uczy „zdziecinniałego" myślenia. Jednak, jeżeli nawet można Brzozowskiemu przyznać rację, bo trylogia jest piękną baśnią o przeszłości, to w ówczesnych warunkach takie pisanie „ku pokrzepieniu serc” było potrzebne. Polacy, upokarzani przez zaborców, Polacy przegrywający kolejne powstania, wynaradawiani i prześladowani - potrzebowali takiej właśnie literatury. Na jej kartach wzorzec Polaka - zwycięskiego rycerza, nawet jeżeli w części (dodajmy: znacznej, biorąc pod uwagę ostateczny upadek państwa, którego owi dzielni „Sarmaci” nie potrafili obronić) mijało się to z prawdą historyczną, był wysoce pożądany. Dodajmy, że ten patriotyczny paradygmat odegrał istotną rolę $\mathrm{z}$ chwilą, gdy w nowych warunkach społecznych należało budzić ducha oporu przeciwko zaborcom - w kręgach robotniczych, a także wśród ludności wiejskiej. Z powodzeniem wykorzystywały go zwłaszcza partia robotnicza (PPS), jak również ruch ludowy, ponadto i dla polskiego Kościoła katolickiego był to czynnik stanowiący swoistą przeciwwagę dla groźnych haseł socjalistycznych solidaryzmu klasowego. Dla podtrzymania spoiwa narodowego wojenna przeszłość naszych antenatów była wartością pierwszorzędną.

W sprzyjających sprawie polskiej okolicznościach I wojny światowej zrobiono wiele, aby ten mit Polaka-żołnierza wcielić w życie. Mimo tragicznej sytuacji, gdy brat $\mathrm{w}$ mundurze pruskim musiał strzelać do brata w mundurze rosyjskim, Polacy nie uchylali się od walki. Myślą przewodnią było odwoływanie się do ugruntowanego mitu, udział $\mathrm{w}$ wojnie $\mathrm{z}$ nadziejami na niepodległość traktowano jako ciągłość, jako wierność tradycji. Doskonale to oddawał wiersz Jerzego Żuławskiego Do moich synów:

Synkowie moi, poszedłem w bój // jako wasz dziadek a ojciec mój Jak ojca ojciec i ojca dziad // co z Legionami przemierzał świat Szukając drogi przez krew i blizny // do naszej wolnej Ojczyzny.

Znamienny też był ostatni fragment tego pięknego wiersza:

Lecz gdyby Pan, nie dał wzejść zorzy z krwi naszych ran (wówczas) i wy pójdziecie pomni puścizny // na bój dla naszej Ojczyzny9.

Walki naszych rodaków, zwłaszcza te toczone w formacjach polskich (oddziały syberyjskie, Armia Hallera), w szczególności zaś Legiony utworzone przez Józefa Piłsudskiego, były znakomitym zaczynem tego, aby po odzyskaniu niepodległości mit Polaka-żołnierza zyskał nowy blask i społeczne poparcie. Wojna stworzyła warunki do odzyskania własnego państwa, w tej wojnie polski żołnierz odegrał istotną rolę, trudno zatem się dziwić, że mit tego żołnierza zajaśniał w kulturze, pieśni, oficjalnej państwowej propagandzie, w szkolnictwie. Dodajmy, że

\footnotetext{
${ }^{9}$ Por. Pieśń nowych Legionów, Wiedeń 1915, s. 21.
} 
ogromną rolę przekonanie o pięknej żołnierskiej z udziałem naszych przodków epopei odgrywało na płaszczyźnie integracji Polaków, tak przecież zróżnicowanych po latach zaborów.

Może zatem powstać pytanie, czy wszystkie te wymienione przez nas, a intensywnie stosowane zabiegi propagandowe i wychowawcze, służące utrwaleniu w społeczeństwie przekonania o szczególnych wartościach żołnierskiego mitu (w odniesieniu do narodowej przeszłości) i żołnierskiej postawy (w odniesieniu do ówczesnej rzeczywistości), miały charakter trwały, czy przełożyły się na tragiczne wydarzenia wojny i okupacji? Wydaje się, że walka wrześniowa, a później walki u boku aliantów każą nam dać odpowiedź twierdzącą. Czasy się zmieniły, a mit Polaka-żołnierza także współcześnie ma się doskonale. Dowodzi tego chociażby obecna ,polityka historyczna”, ale to już zupełnie inny temat.

Na zakończenie naszych rozważań, wracając do tytułowego pytania: Polonus militans - mit to czy prawda?, winniśmy się zastanowić, jak powinna brzmieć prawidłowa odpowiedź? Nie jest ona prosta. W okresie I Rzeczpospolitej specyfika ustrojowa, która zrodziła się na kanwie szczególnej pomyślności gospodarczej i w warunkach względnie długiego okresu pokojowego bytowania państwa, spowodowała, że elementy militarne w znacznej mierze funkcjonowały jedynie na płaszczyźnie kulturowej, w sferze samooceny „narodu politycznego”, podczas gdy rzeczywiste potrzeby wojenne państwa zaspokajane były wysiłkiem monarchy i wojsk magnackich. Natomiast zgodnie ze swoistą prawidłowością funkcjonowania zjawisk społecznych im mniejszy był udział szlachty w obronie kraju, tym silniej funkcjonował mit o jej szczególnych na tym polu zasługach. Dalecy jesteśmy od głoszenia tezy, że szlachta nie ponosiła faktycznych zasług na polu walki zarówno w wymiarze finansowym, jak i przez osobisty udział, zwłaszcza w drugiej połowie XVII w., ale był to udział „wymuszony”, który stał w wyraźnej sprzeczności z postawą pacyfistyczną. W okresie sarmatyzmu przekonanie o szczególnej waleczności szlachcica obrońcy wiary i ojczyzny stało się chyba najważniejszą częścią tego mitu. Powtórzmy: mitu, ponieważ rzeczywistość sprowadzała się głównie do płaszczyzny kulturowej. W wieku XIX postrzeganie Polaka-wojownika pozwalało w sferze kulturowej mit ten pielęgnować, a potwierdzać w odniesieniu do walk u boku Napoleona, a później w przegranych kolejnych zrywach niepodległościowych. Konieczność utrzymywania tego mitu była bezsporna, z tym wszelako, że teraz pełnił on funkcję terapeutyczną, był remedium na upokorzenia ze strony zaborców. W dwudziestoleciu międzywojennym mit ten zabłysnął w pełnej krasie. I wówczas to w stopniu chyba w naszych dziejach najbardziej zasłużonym. Wojna z istotnym udziałem polskiego żołnierza (zwłaszcza wojna z Rosją i walki z Niemcami o granicę zachodnią) niepodległość utrwaliła. Żołnierskie wartości przyczyniały się do integracji społeczeństwa złożonego z trzech jakże zróżnicowanych części, a narastające poczucie zagrożenia w postawie patriotyczno-żołnierskiej kazało szukać oparcia na przyszłość. Postawa społeczeństwa podczas wojny 1939 r., niespotykany w Europie na taką skalę, 
jak w Polsce ruch oporu podczas okupacji postrzeganie Polaka jako żołnierza zdają się w pełni potwierdzać. Czy jednak współczesne potrzeby nowoczesnego społeczeństwa podtrzymywanie tego mitu, jego kontynuację czynią zasadną?

\section{Bibliografia}

\section{OPRACOWANIA}

Araszkiewicz F.W., Ideały wychowawcze Drugiej Rzeczypospolitej, Warszawa 2011.

Błoński J., Mikołaj Sẹp Szarzyński a początki polskiego baroku, Kraków 1996.

Estreicher S., Pacyfizm w Polsce XVI stulecia, Poznań 1930.

Goliński J.K., Okolice trwogi: lęk w literaturze i kulturze dawnej Polski, Bydgoszcz 1997.

Górski J., Męska rzecz, Warszawa-Bielsko-Biała 2011.

Homer, Iliada, przekł., wstępem i komentarzem opatrzył J. Łanowski, Wrocław 1986.

Ideały wychowania $i$ wzory osobowe narodu polskiego w XIX i XX wieku, t. I-II, red. E.J. Kryńska, Białystok 2006.

Janion M., Kobiety i duch inności, Warszawa 1996.

Janion M., Płacz generata. Eseje o wojnie, Warszawa 1998.

Janion M., Reduta. Romantyczna poezja niepodległościowa, Kraków 1979.

Kaltenbergh L., Kopczyk zacny sławy żołnierskiej w dawnej legendzie, dokumencie, porzekadle, opowieści, przekazie, gadce i pamiętniku, Warszawa 1975.

Kapuściak J., Podgórski W.J., Tradycje żołnierskie w literaturze polskiej, Wrocław 1978.

Kochanowski J., Dzieła polskie, oprac. J. Krzyżanowski, t. I, Warszawa 1976.

Krzyżanowski J.R., Legenda Samosierry i inne prace krytyczne, Warszawa 1987.

Lenart M., „Miles pius et justus”. Żotnierz chrześcijański katolickiej wiary w kulturze i piśmiennictwie dawnej Rzeczypospolitej (XVI-XVIII w.), Warszawa 2009.

Micińska M., Między Królem Duchem a mieszczaninem. Opis bohatera narodowego piśmiennictwie polskim przełomu XIX i XX w. (1890-1914), Wrocław 1995.

Niemcewicz J.U., Śpiewy historyczne, Kraków 1816.

Nietzsche F., Tako rzecze Zaratustra, przekł. W. Berent, Poznań 2006.

Nowoczesność i sarmatyzm, red. P. Czapliński, Poznań 2011.

Palczewski P., Kolenda moskiewska, Kraków 1609.

Pieśń nowych Legionów, Wiedeń 1915.

Platon, Leches, przekł. W. Witwicki, Warszawa1958.

Polska powieść historyczna XX wieku, red. L. Ludorowski, Lublin 1990.

Problemy literatury staropolskiej, seria III, red. J. Pelc, Wrocław 1978.

Sarmackie Teatrum, t. I-II, red. R. Ocieczek, Katowice 2001.

Sęp Szarzyński M., Poezje, wstęp i oprac. J.S. Gruchała, Kraków 1997.

Sowa J., Fantomowe ciało króla, Kraków 2011.

Świderska-Włodarczyk U., Homo militans, Warszawa 2018.

Tazbir J., Kultura szlachecka w Polsce, Poznań 1998. 
Tomasik T., Wojna - męskość - literatura, Słupsk 2013.

Wańkowicz M., Wojna i pióro, Warszawa 1983.

Wilson P.H., Wojna trzydziestoletnia 1618-1648. Tragedia Europy, Oświęcim 2017.

Wojna - doświadczenie i zapis. Nowe źródła, problemy, metody badawcze, Kraków 2006.

Wojny, bitwy i potyczki w kulturze staropolskiej, red. W. Pawlak, M. Piskuła, Warszawa 2011.

\section{Karol Olejnik}

\section{Polish warrior. An example of a Polish man - myth or reality?}

\footnotetext{
The article approaches the culture problem between myths about extraordinary bravery of 1 Polish men and the historical facts which are different from this stereotype. This article focuses on the roots of the myth and its permanent place in Polish culture.
}

Keywords: Polish, men, warrior, knight, soldier - culture stereotypes. 